\title{
The Role of Glucagon Deficiency in the Houssay Phenomenon of Dogs
}

\author{
hajime Nakabayashi, Richard E. Dobbs, and Roger H. Unger, Veterans \\ Administration Hospital and Department of Internal Medicine, The \\ University of Texas Southwestern Medical School, Dallas, Texas 75235, \\ and The Institute of Histology and Embryology, University of Geneva, \\ School of Medicine, Geneva, Switzerland
}

\begin{abstract}
A в S T R A C T Plasma glucose, immunoreactive glucagon (IRG), and insulin were measured in hypophysectomized dogs receiving cortisol and thyroid replacement therapy. $4 \mathrm{wk}$ after hypophysectomy mean fasting plasma glucose levels had declined from $90 \pm 2$ $\mathrm{mg} / 100 \mathrm{ml}$ to $64 \pm 2$; fasting and arginine-stimulated insulin and IRG levels were, respectively, $\sim 50 \%$ lower and unchanged. $12 \mathrm{wk}$ or more after hypophysectomy, despite lower plasma glucose levels, fasting and arginine-stimulated IRG levels were significantly below control dogs. Hypophysectomized and shamhypophysectomized dogs were subjected to total pancreatectomy. Postoperatively, in the sham-hypophysectomized, depancreatized dogs fasting glucose levels ranged from $300-500 \mathrm{mg} / 100 \mathrm{ml}$ on $8-10 \mathrm{U} /$ day of insulin; IRG levels averaged $215 \pm 29 \mathrm{pg} / \mathrm{ml}$. The hypophysectomized, depancreatized dogs required 0 $4 \mathrm{U} /$ day and fasting glucose levels under $100 \mathrm{mg} / 100$ $\mathrm{ml}$ were not uncommon, even without insulin; fasting IRG levels averaged $63 \pm 4 \mathrm{pg} / \mathrm{ml}(P<0.001)$. During arginine infusion in sham-hypophysectomized, depancreatized dogs, IRG levels rose from $215 \pm 60 \mathrm{pg} / \mathrm{ml}$ to a peak of $404 \pm 112 \mathrm{pg} / \mathrm{ml}$; in hypophysectomized, depancreatized dogs, the base line IRG averaged $44 \pm 8$ and the peak $110 \pm 25 \mathrm{pg} / \mathrm{ml}(P<0.05)$. IRG levels in the venous effluent of the gastric fundus, the major source of nonpancreatic glucagon, reached a peak of $4,898 \pm 959 \mathrm{pg} / \mathrm{ml}$ in the sham-hypophysectomized, depancreatized group during arginine infusion and only $219 \pm 128 \mathrm{pg} / \mathrm{ml}$ in the hypophysectomized, depancreatized group. In three hypophysectomized, depancreatized dogs, a replacement infusion with glucagon for $10 \mathrm{~h}$ promptly increased hyperglycemia by $80-180 \mathrm{mg} / 100 \mathrm{ml}$ and worsened glycosuria, evidence of a hepatic response to glucagon replacement. It is concluded that hypophysectomy somehow de-
\end{abstract}

Presented at the American Physiological Society, 13 October 1977, Hollywood, Fla.

Received for publication 19 August 1977 and in revised form 13 January 1978 . creased both the hypersecretion of gastric IRG and the severe hyperglycemia that otherwise follows pancreatectomy. The hypophysectomized, depancreatized animal, therefore, has combined insulin and glucagon deficiency, and the latter may contribute to reduced severity of its hyperglycemia.

\section{INTRODUCTION}

In 1930 Houssay and Biassotti reported that hypophysectomized, totally depancreatized dogs required little or no insulin and frequently exhibited normal or low levels of glucose even without insulin treatment (1). Subsequently it was demonstrated that the administration of anterior pituitary (2) or adrenal cortical extracts (3) to hypophysectomized, depancreatized animals rapidly worsened their diabetes. It was concluded that the anterior hypophysis is necessary for the establishment of severe diabetes (4).

Two lines of evidence suggest that the improved metabolic state of the hypophysectomized, depancreatized dog might be mediated by a deficiency of glucagon secondary to a reduction in corticosteroids and(or) growth hormone (5-14). First, it has been reported that glucocorticoids increase both the A-cell response to aminogenic stimulation $(5,6)$ and the sensitivity of the liver to glucagon $(7,8)$, suggesting that the adrenocortical insufficiency secondary to pituitary ablation might reduce the secretion and(or) biologic effectiveness of glucagon. Second, growth hormone itself may enhance glucagon secretion; growth hormone increases the hyperglycemic activity of the pancreatic venous effluent of cats and dogs $(9,10)$, and the secretion of immunoreactive glucagon $(11,12)$, and glucagon levels are reported to be high in acromegalics $(13,14)$. It would not be surprising, therefore, if glucagon levels were reduced by hypophysectomy, and then further reduced by total pancreatectomy, which would leave the gastric fundus as the major site of glucagon secretion (15-18). The present studies 
were designed to test the hypothesis that hypophysectomy reduces circulating nonpancreatic glucagon after total pancreatectomy in dogs (19-21) and that the Houssay syndrome may, therefore, be an example of hypoglucagonemic diabetes.

\section{METHODS}

After an overnight fast, male mongrel dogs weighing 18-25 $\mathrm{kg}$ were anesthetized with pentobarbital sodium (25-30 $\mathrm{mg} / \mathrm{kg}$ body weight) and a transtemporal hypophysectomy (hypoX) ${ }^{1}$ was performed by the method of Crowe, et al. (22). The completeness of the operation was ultimately confirmed at autopsy by macroscopic and microscopic examination of the tissues in the sella turcica and the stalk region. Initial clinical confirmation was made by demonstration of declining plasma cortisol and thyroxine levels postoperatively. After laboratory evidence of adrenal and thyroid insufficiency had been obtained, the hypoX dogs were maintained on twice daily $5 \mathrm{mg}$ of hydrocortisone sodium succinate (Cortef, Upjohn Co., Kalamazoo, Mich.) and $50 \mu \mathrm{g}$ of L-thyroxine daily, both given by mouth. At 7 a.m. and at 3 p.m. each day they were fed a diet consisting of $380 \mathrm{~g}$ Purina dog chow (Ralston Purina Co., Inc., St. Louis, Mo.) plus $200 \mathrm{~g}$ canned dog food.

In a group of seven dogs a sham hypoX was performed with the same surgical procedure except that the pituitary gland was not removed. No replacement therapy was given to this group. Their weights ranged from 28.1 to $25.2 \mathrm{~kg}$ with an average of $23.5 \mathrm{~kg}$.

1-4 mo after the intracranial procedures, a total pancreatectomy was performed in both the hypoX and shamhypoX dogs under pentobarbital sodium anesthesia. The hypoX dogs received $100 \mathrm{mg}$ of hydrocortisone sodium succinate (Solu-Cortef, Upjohn Co.) intravenously $30 \mathrm{~min}$ before anesthesia and $25 \mathrm{mg}$ of cortisol intramuscularly twice daily for 2 postoperative days. Thereafter, they were again maintained on $5 \mathrm{mg}$ of intramuscular cortisol twice daily and L-thyroxine $(50 \mu \mathrm{g} /$ day), Cotazyme (Organon Pharmaceuticals, West Orange, N. J.), and Hexavitamin tablets (R. P. Scherer Corp., Detroit, Mich.) given twice daily. Their weights ranged from 24.5 to $25.9 \mathrm{~kg}$ with an average of $25.2 \mathrm{~kg}$. Completeness of the pancreatectomy was ultimately substantiated at autopsy in all dogs. No pancreatic remnants or aberrant pancreatic tissue were found at autopsy in any dog.

The hypoX-pancreatectomized dogs, weighing from 20 to $22 \mathrm{~kg}$, with an average weight of $21 \mathrm{~kg}$, received either no insulin or from $1-2 \mathrm{U}$ of regular insulin twice daily. The sham-hypoX, pancreatectomized dogs, weighing from 19.5 to $28 \mathrm{~kg}$, with an average weight of $21.8 \mathrm{~kg}$, received $4-5 \mathrm{U}$ of regular insulin twice daily. Insulin was administered just after a meal. Food intake was maintained at a constant level in all dogs by tube feeding whenever a dog did not finish a meal. In dogs receiving insulin therapy, insulin was discontinued $42 \mathrm{~h}$ before an experiment. Hormone replacement and diet were withheld $17-18 \mathrm{~h}$ before the start of an experiment.

A group of five bilaterally adrenalectomized dogs, maintained on $7.5 \mathrm{mg}$ of cortisol given intramuscularly twice daily, was studied $3 \mathrm{wk}$ or more after surgery while on cortisol replacement therapy and again 4-5 days after with-

${ }^{1}$ Abbreviations used in this paper: hypoX, hypophysectomy, hypophysectomized; IRG, immunoreactive glucagon. drawal of cortisol therapy. Their weights ranged from 19 to $22.7 \mathrm{~kg}$ with an average weight of $21.8 \mathrm{~kg}$. The studies involved arginine infusion tests conducted in the conscious state as described below for the other groups of dogs.

In each dog three 15-min intravenous arginine infusions $(0.5 \mathrm{~g} / \mathrm{kg}$ per $30 \mathrm{ml})$ were conducted with the dog in a conscious state. The first such test was carried out before any surgical procedure, the second 4 or 12 wk after either hypoX or sham-hypoX and before pancreatectomy, and the third 1 wk after pancreatectomy in the sham-hypoX, depancreatized dogs and 1-3 wk after pancreatectomy in the hypoX-depancreatized dogs ( $1 \mathrm{wk}$ after pancreatectomy in three of the six dogs). Blood samples were obtained through a catheter inserted in a peripheral leg vein.

Two 15-min arginine infusion experiments were also conducted during laparotomy, the first just before pancreatectomy and the second just before sacrifice of the dogs so as to obtain simultaneous blood samples from the inferior vena cava, the short gastric vein, and the portal vein. In these studies the dogs of all groups received an intravenous injection of $100 \mathrm{mg}$ of hydrocortisone $30 \mathrm{~min}$ before the pentobarbital sodium anesthesia. A 60 -min equilibration period, during which only saline was infused, preceded the arginine infusion.

Plasma glucose was determined by the glucose oxidase method (23) using a glucose analyzer (Beckman Instruments, Inc., Fullerton, Calif.). Insulin was determined by the radioimmunoassay of Yalow and Berson (24), as modified by Herbert et al. (25). Immunoreactive glucagon (IRG) was measured as described previously (26) with $30 \mathrm{~K}$ antiserum, which is considered to be reactive with the $C$-terminal portion of the glucagon molecule $(27,28)$ and which crossreacts only very weakly with gut glucagon-like immunoreactivity (29).

For the statistical analyses, paired and unpaired Student $t$ tests were employed.

\section{RESULTS}

Effect of hypoX on glucose, insulin, and IRG levels in the fasting state and during arginine infusion. The fasting glucose level of a group of 16 normal dogs averaged $90 \pm 2 \mathrm{mg} / 100 \mathrm{ml}$; in nine dogs $4 \mathrm{wk}$ after hypoX it averaged $64 \pm 2 \mathrm{mg} / 100 \mathrm{ml}$ despite cortisol and thyroid replacement therapy $(P<0.01)$, and was below the control group at all time points during the arginine infusion $(P<0.001)$ (Fig. 1). In the control dogs mean plasma insulin levels rose from $13.2 \pm 1.6$ at 0 min to a mean peak of $34.5 \pm 3.2$ at 1.5 min during arginine infusion; in the hypoX group, insulin averaged $7.1 \pm 0.5 \mu \mathrm{U} / \mathrm{ml}$ at $0 \mathrm{~min}$ and rose to a mean peak of only $18.8 \pm 2.8$ at $3 \mathrm{~min}$, significantly below the control levels at all time points $(P<0.01)$. Mean fasting and arginine-stimulated IRG levels and the mean of glucagon increments during arginine infusion were similar in the two groups.

Five dogs were studied $12 \mathrm{wk}$ or more after the hypoX. Fasting glucose levels before and during arginine infusion were below normal, averaging $66 \pm 3$ $\mathrm{mg} / 100 \mathrm{ml}$ before the infusion and rising to a peak of $74 \pm 2 \mathrm{mg} / 100 \mathrm{ml}$ at $5 \mathrm{~min}$. Mean basal and argininestimulated insulin levels were significantly reduced at all time points to less than one-half the values of 


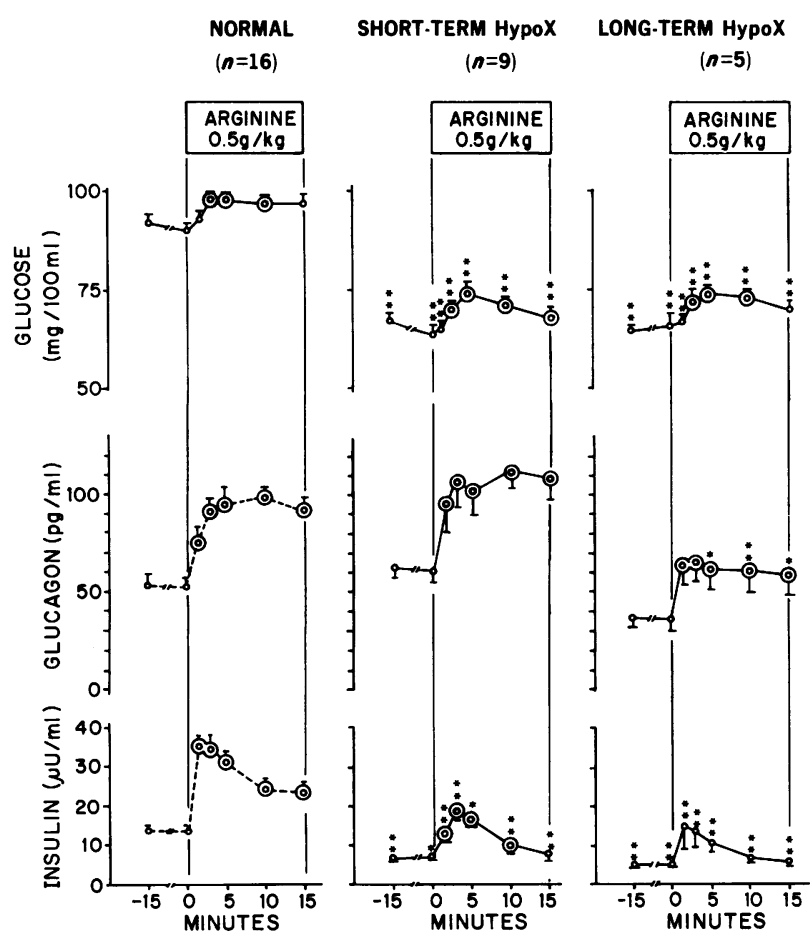

Figure 1 Comparison of peripheral venous plasma glucose, IRG, and insulin levels in normal dogs and in dogs $4 \mathrm{wk}$ after hypoX (short-term) and $12 \mathrm{wk}$ after hypoX (long-term). $\mathrm{O}=$ significant vs. values at $0 \mathrm{~min}(P<0.05){ }^{*}=P<0.05$; $*_{*}^{*}=P<0.01$ vs. normal. the normal dogs, and were significantly lower than those of the short-term hypoX group at 0 and $10 \mathrm{~min}$ $(P<0.05)$. Plasma IRG levels in this group averaged $35 \pm 5 \mathrm{pg} / \mathrm{ml}$ at $0 \mathrm{~min}$ and rose to a peak of only $65 \pm 8$ at $3 \mathrm{~min}$. The mean of IRG increments during arginine infusion was only $37 \pm 9 \mathrm{pg} / \mathrm{ml}$, significantly below the value of $69 \pm 9 \mathrm{pg} / \mathrm{ml}$ in the short-term hypoX group $(P<0.05)$.

Because the stomach is the principle source of IRG after pancreatectomy (20), studies were undertaken to determine if gastric IRG release was reduced $12 \mathrm{wk}$ after hypoX. An arginine test was performed in four dogs during laparotomy and blood samples were collected simultaneously from the short gastric vein, portal vein, and inferior vena cava. As shown in Fig. 2, gastric vein IRG levels before and during arginine infusion were less than one-half those of the shamhypoX control group ( $P<0.05$ at 5,10 , and $15 \mathrm{~min}$ ).

The effect of discontinuing cortisol replacement therapy upon plasma glucose, IRG, and insulin levels in hypoX and adrenalectomized dogs. To assess the effect of discontinuation of glucocorticoid replacement therapy on the various changes observed in the nine hypoX dogs, an arginine test was repeated after three wk without cortisol administration when plasma cortisol had become unmeasurable. As shown in Fig. 3, plasma glucose levels were significantly less than during replacement therapy at all points, averaging $53 \pm 1 \mathrm{mg} / 100 \mathrm{ml}$ at $0 \mathrm{~min}$. Fasting and

SHAM-HypoX

SHORT-TERM HyPOX

LONG-TERM HypoX
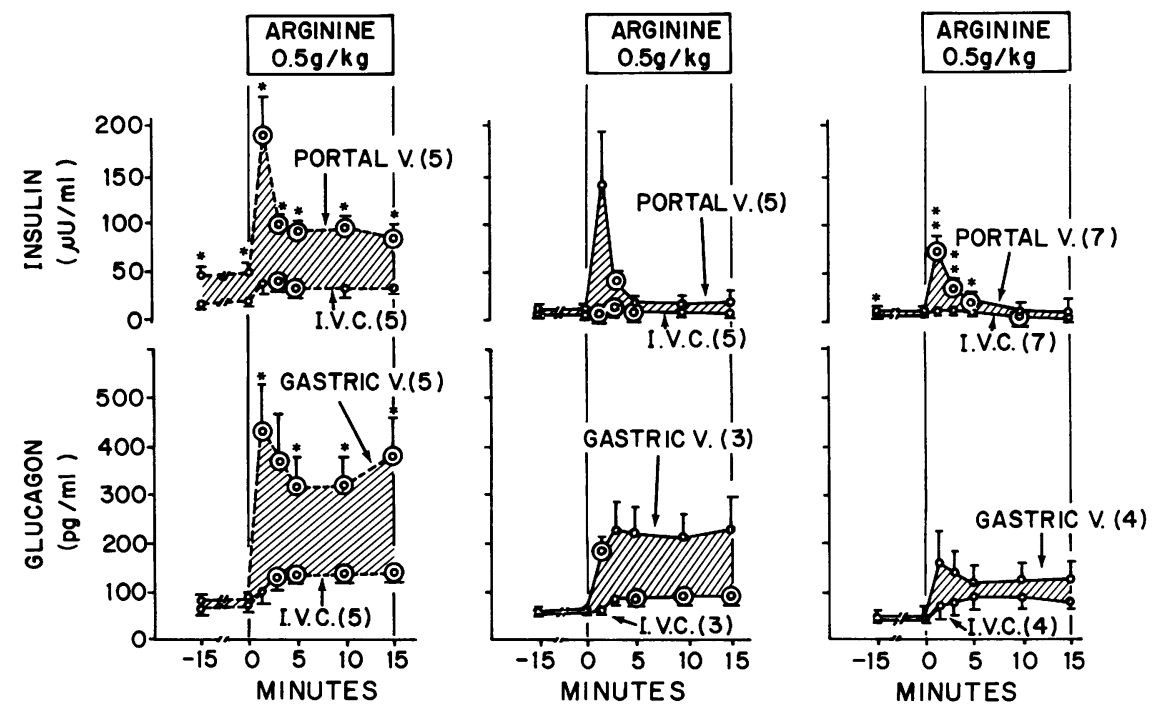

FIGURE 2 Comparison of plasma levels of immunoreactive insulin and glucagon in the inferior vena cava (I.V.C.), portal vein, and gastric vein of sham-hypoX dogs, dogs 4 wk after hypophysectomy (short-term hypoX) and $12 \mathrm{wk}$ after hypoX (long-term hypoX). ${ }^{*}=P<0.05$; ${ }_{*}^{*}=P<0.01$ vs. I.V.C.; $O=$ significant vs. values at $0 \mathrm{~min}(P<0.05) ;(\quad)=$ numbers. 


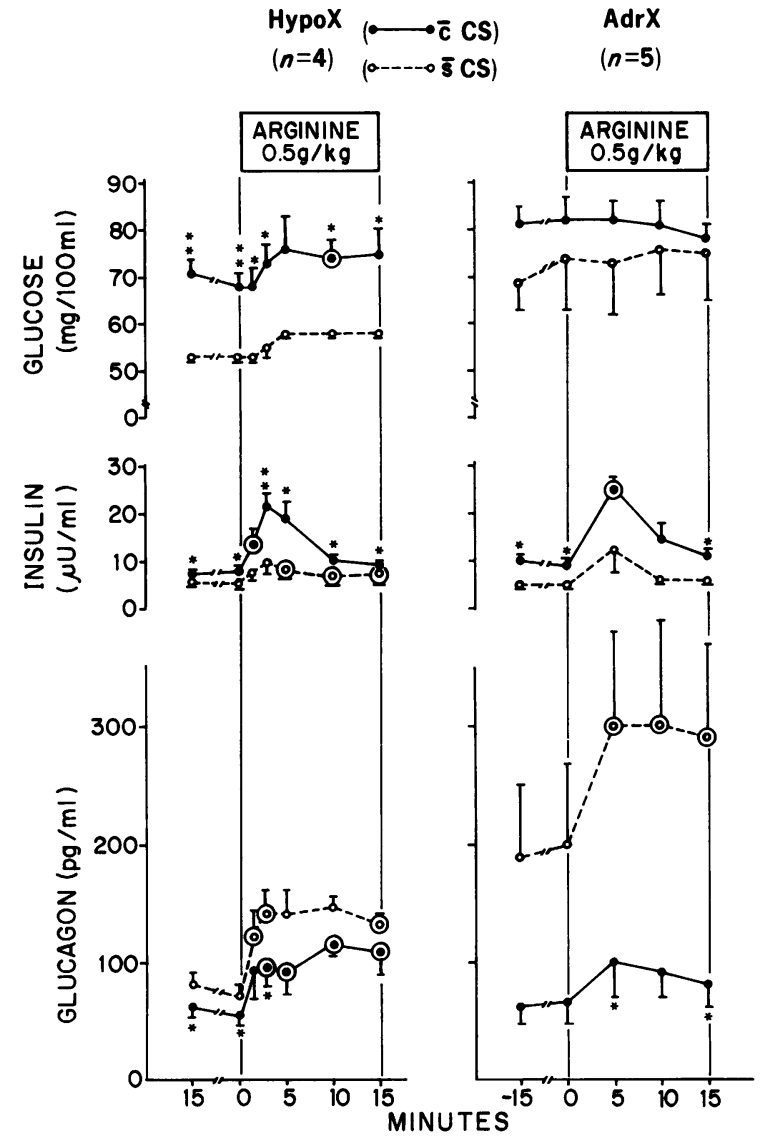

Figure 3 Comparison of plasma glucose and immunoreactive insulin and glucagon levels in dogs 10-13 wk after hypoX with and without cortisol (CS) replacement therapy and totally adrenalectomized (AdrX) dogs with and without cortisol replacement. ${ }^{*}=P<0.05 ; \underset{*}{*}=P<0.01$ vs. $\overline{\text { s }} \mathrm{CS}$; $\bigcirc$ $=$ significant vs. values at $0 \min (P \stackrel{*}{<0.05})$.

arginine-stimulated insulin levels were also significantly below the values during cortisol replacement. Fasting and arginine-stimulated IRG levels were somewhat higher, but the difference was significant only at 0 and $3 \mathrm{~min}(P<0.05)$.

To compare the foregoing consequences of cortisol withdrawal in secondary adrencortical insufficiency with those of primary adrenal insufficiency, five bilaterally adrenalectomized animals were given arginine infusion tests while on $7.5 \mathrm{mg}$ of cortisol twice daily and again 4-5 days after its discontinuation (Fig. 3 ). Cortisol withdrawal was associated with a modest reduction in plasma glucose, a significant decrease in insulin, and a marked increase in both base line and arginine-stimulated IRG levels $(P<0.05$ at 5 and 15 $\mathrm{min})$. Although the reduction in plasma glucose levels was less marked, mean IRG levels were higher (NS) than in cortisol-deprived hypoX dogs.

Comparison of fasting glucose and IRG levels in
hypoX, depancreatized, and sham-hypoX, depancreatized dogs. Fasting plasma glucose and IRC levels were measured daily or every other day in the sham-hypoX, depancreatized dogs and the hypoX, depancreatized dogs (Fig. 4). In sham-hypoX, depancreatized dogs receiving 8-10 U insulin daily, glucose levels ranged from 300 to $560 \mathrm{mg} / 100 \mathrm{ml}$. IRG levels averaged $215 \pm 29 \mathrm{pg} / \mathrm{ml}$ and ranged from 35 to 900 $\mathrm{pg} / \mathrm{ml}$. IRG increased with time after pancreatectomy (Fig. 4).

By contrast, in the hypoX, depancreatized dogs, the insulin dose could be omitted without precipitating the inexorable metabolic deterioration associated with insulin deprivation in depancreatized dogs. The prevalence of low glucose values increased after the 1st wk after pancreatectomy (Fig. 4). 13 random glucose levels under $200 \mathrm{mg} / 100 \mathrm{ml}$ were observed in six dogs and seven of them were $100 \mathrm{mg} / 100 \mathrm{ml}$ or less. (One dog, omitted from the study because of loss of consciousness and moribund status attributed to severe hypoglycemia, had a glucose level of $10 \mathrm{mg} / 100 \mathrm{ml} 24 \mathrm{~h}$ after his last injection of regular insulin). IRG levels in the hypoX, depancreatized dogs ranged between 15 and $140 \mathrm{pg} / \mathrm{ml}$ and averaged $63 \pm 4 \mathrm{pg} / \mathrm{ml}$, significantly less than the sham-hypoX, depancreatized group $(P<0.001)$. Like the glucose levels, low values became more prevalent with time after pancreatectomy and after the 7th post-pancreatectomy day no fasting IRG value over $100 \mathrm{pg} / \mathrm{ml}$ was noted.

Comparison of plasma glucose and IRG levels in hypoX, depancreatized, and sham-hypoX, depancreatized dogs before and during arginine infusion. An arginine infusion was carried out in the six shamhypoX, depancreatized dogs and the six hypoX, depancreatized dogs. In the sham-hypoX, depancreatized dogs, fasting plasma glucose averaged $376 \pm 10 \mathrm{mg} / 100$ $\mathrm{ml}$ and rose to a peak of $389 \pm 11 \mathrm{mg} / 100 \mathrm{ml}$ at 3 min, whereas in the six hypoX, depancreatized dogs it averaged $210 \pm 60 \mathrm{mg} / 100 \mathrm{ml}$ and rose slowly to a peak of $236 \pm 60 \mathrm{mg} / 100 \mathrm{ml}$ at $15 \mathrm{~min}$ (Fig. 5). Mean glucose levels of the hypoX, depancreatized group were significantly less than those of the sham-hypoX, depancreatized group at all time points.

In the sham-hypoX, depancreatized dogs, mean plasma IRG averaged $215 \pm 60 \mathrm{pg} / \mathrm{ml}$ at $0 \mathrm{~min}$ and rose with arginine infusion to $404 \pm 112$ at $15 \mathrm{~min}$. In the hypoX, depancreatized group it averaged $47 \pm 8 \mathrm{pg} / \mathrm{ml}$ at $0 \mathrm{~min}$ and rose to a peak of only $110 \pm 25$ at 10 min; IRG levels were significantly less at all time points $(P<0.05)$.

To determine if the lower IRG levels in the hypoX, depancreatized dogs were the result of reduced gastric IRG release, a final arginine test was carried out in sham-hypoX, depancreatized and hypoX, depancreatized dogs during laparotomy just before sacrifice, and blood samples were obtained simultaneously from 

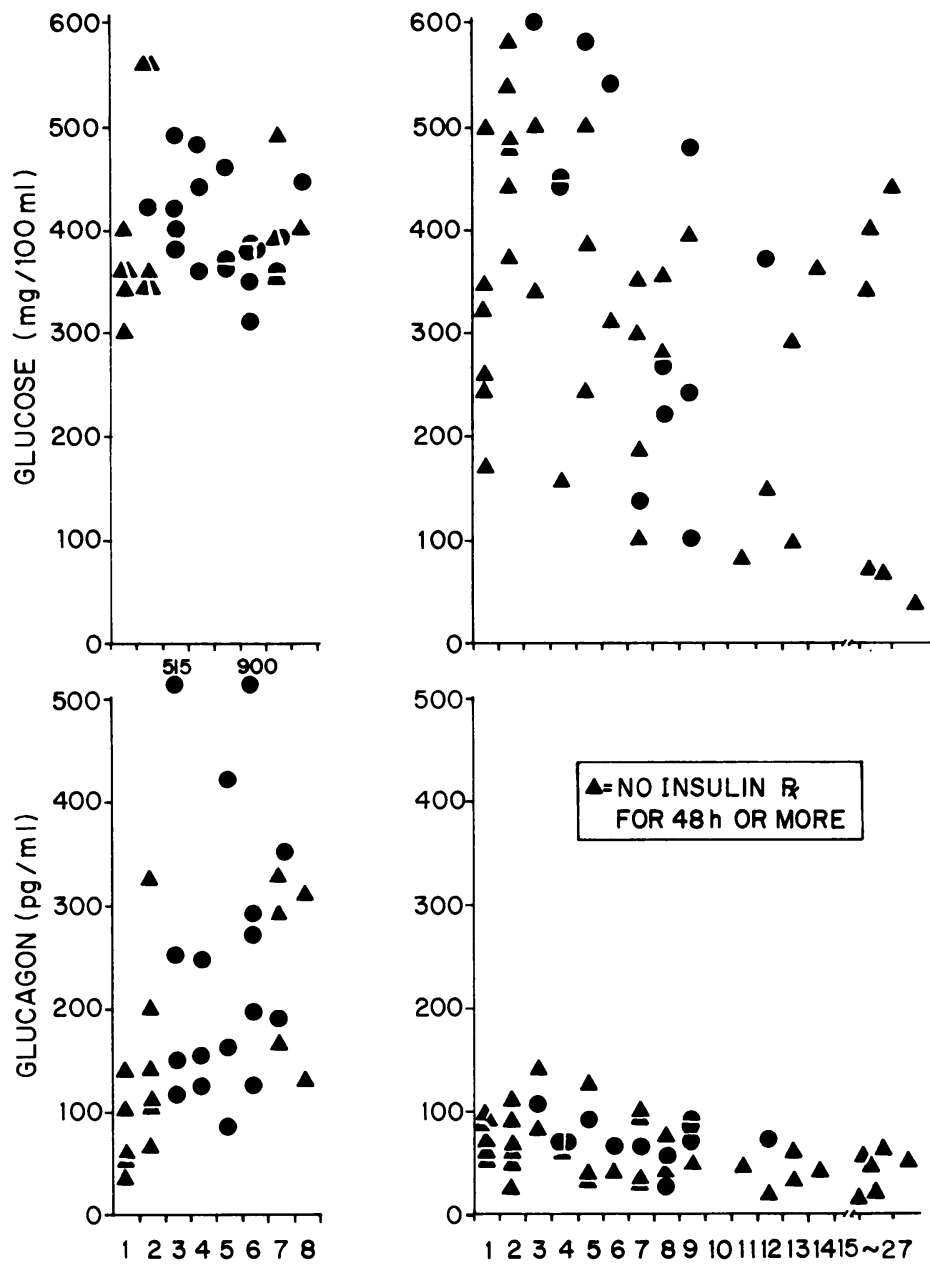

POSTOPERATIVE DAYS

FIGURE 4 Daily fasting glucose and IRG levels in sham-hypoX, pancreatectomized dogs (shamHoussay) and in hypoX, pancreatectomized (Houssay) dogs.

the short gastric, the portal vein, and the inferior vena cava. In the sham-hypoX, depancreatized dogs (Fig. 6), the mean fasting IRG level in the gastric vein was $1915 \pm 521 \mathrm{pg} / \mathrm{ml}$ and rose during arginine infusion to a peak of $4,898 \pm 959$. In the hypoX, depancreatized animals, by contrast, the fasting and peak arginine-stimulated IRG levels in the gastric vein averaged only $47 \pm 17$ and $219 \pm 128$, respectively, significantly less at all time points than in the sham-hypoX, depancreatized dogs $(P<0.05)$. Portal vein levels of IRG were also less in the hypoX, depancreatized dogs.

Effect of a replacement infusion of glucagon on the glycemia of hypoX, depancreatized dogs. To determine if an increase in circulating glucagon to the levels present in the portal vein of the sham-hypoX, depan- creatized dogs would enhance the severity of their diabetes, three hypoX, depancreatized dogs received a constant intravenous infusion of glucagon at rates from 2.5 to $10 \mathrm{ng} / \mathrm{kg}$ per min for up to $11 \mathrm{~h}$ (Fig. 7). IRG levels had been below $50 \mathrm{pg} / \mathrm{ml}$ before the infusions and they rose to a maximum of $1,000 \mathrm{pg} / \mathrm{ml}$, but were for the most part below the range of portal vein IRG levels of the sham-hypoX, depancreatized dogs. Nevertheless, glucose levels, which were $\sim 200 \mathrm{mg} / 100 \mathrm{ml}$ before the infusion, rose promptly in two of the three experiments and, although food was withheld, they ranged between 250 and $460 \mathrm{mg} / 100 \mathrm{ml}$ during the glucagon infusion. Glycosuria increased from a preinfusion value of 0.20 to $1.7 \mathrm{~g} / \mathrm{h}$, and declined when the glucagon infusion was terminated. 


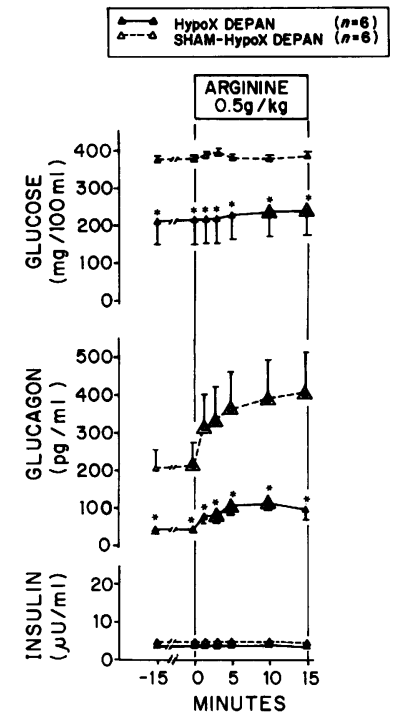

FigURE 5 Comparison of peripheral venous plasma glucose, IRG and insulin levels in hypoX, pancreatectomized (Houssay) and sham-hypoX, pancreatectomized (sham-Houssay) dogs before and during the infusion of arginine. ${ }^{*}=P<0.05$ vs. sham-Houssay; $\Delta=$ significant vs. values at $0 \mathrm{~min}(P$ $<0.05$ ).

\section{DISCUSSION}

These studies once again confirm the observation made by Houssay and Biassotti almost half a century ago that hypoX strikingly reduces the hyperglycemia and insulin requirements of the diabetic state produced by total pancreatectomy (1). Low fasting plasma glucose levels in dogs receiving either no insulin or only 1-4 U of insulin daily became more prevalent with time after pancreatectomy despite replacement doses of cortisol and maintenance of a constant food intake. However, in sham-hypoX, depancreatized dogs receiving 8-10 U of daily insulin, glucose levels remained above 300 $\mathrm{mg} / 100 \mathrm{ml}$ until the time of their sacrifice.

The findings demonstrate a reduction in basal and arginine-stimulated IRG levels $12 \mathrm{wk}$ after hypoX in otherwise intact dogs, despite lower plasma glucose levels. Discontinuation of cortisol replacement therapy elicited only a modest increase in IRG levels despite the accompanying hypoglycemia, in contrast to a twoto threefold rise in IRG levels after cortisol withdrawal in bilaterally adrenalectomized dogs with less hypoglycemia. These results demonstrate that the capacity to enhance IRG during the hypoglycemia caused by steroid withdrawal is less in long-term hypoX dogs than in adrenalectomized dogs.

The lower plasma glucose levels $12 \mathrm{wk}$ after hypoX may not have been the primary consequence of hypoglucagonemia, inasmuch as they were present $4 \mathrm{wk}$ after hypoX, at which time both basal and argininestimulated IRG levels were slightly above normal, presumably in response to the hypoglycemia, as observed in rats by Van Lan et al. (29). Nevertheless, one can argue that the absence of hyperglucagonemia sufficient to correct the hypoglycemia represents evidence of insufficient A-cell function. At 12 wk the same degree of hypoglycemia was present despite lower insulin levels, and IRG levels had declined further, again suggesting an obtunded response by Acells. The low insulin levels, the cortisol replacement, and the constant food intake appear to exclude, respectively, insulin excess, cortisol lack, and starvation as possible causes of the hypoglycemia. Because the arginine-induced rise in plasma glucose was not significantly reduced $12 \mathrm{wk}$ post-hypoX, it seems unlikely that the hypoglycemia was the result of either glycogen depletion or hepatic insensitivity to the biologic actions of glucagon.

After total pancreatectomy in dogs, the gastric fundus is the major source of circulating IRG (18), and clearly

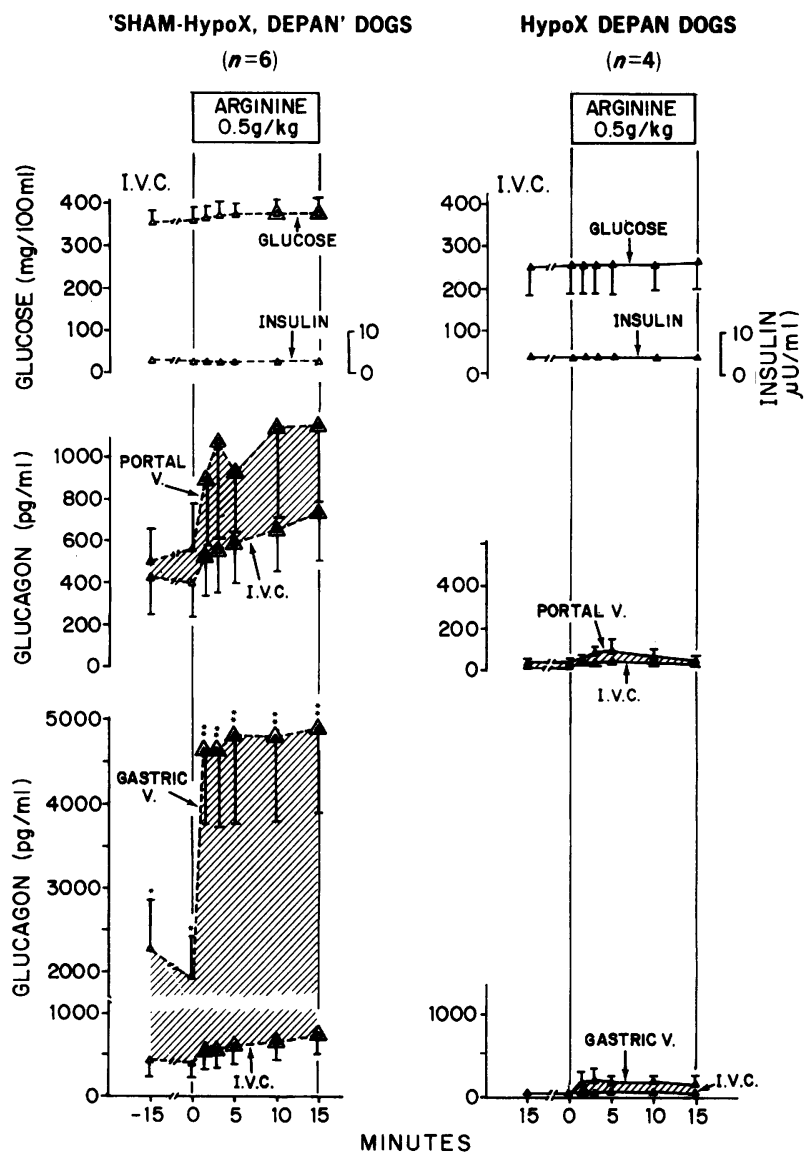

FIGURE 6 Comparison of plasma glucose and IRG and insulin levels in the inferior vena cava (I.V.C.) and IRG levels in the portal and gastric veins of hypoX, depancreatized (Houssay) and sham-Houssay dogs before and during arginine infusion. ${ }^{*}=P<0.05 ;{ }_{*}^{*}=P<0.01$ vs. I.V.C.: $\triangle=$ significant vs. $0 \mathrm{~min}(P<0.05)$. 

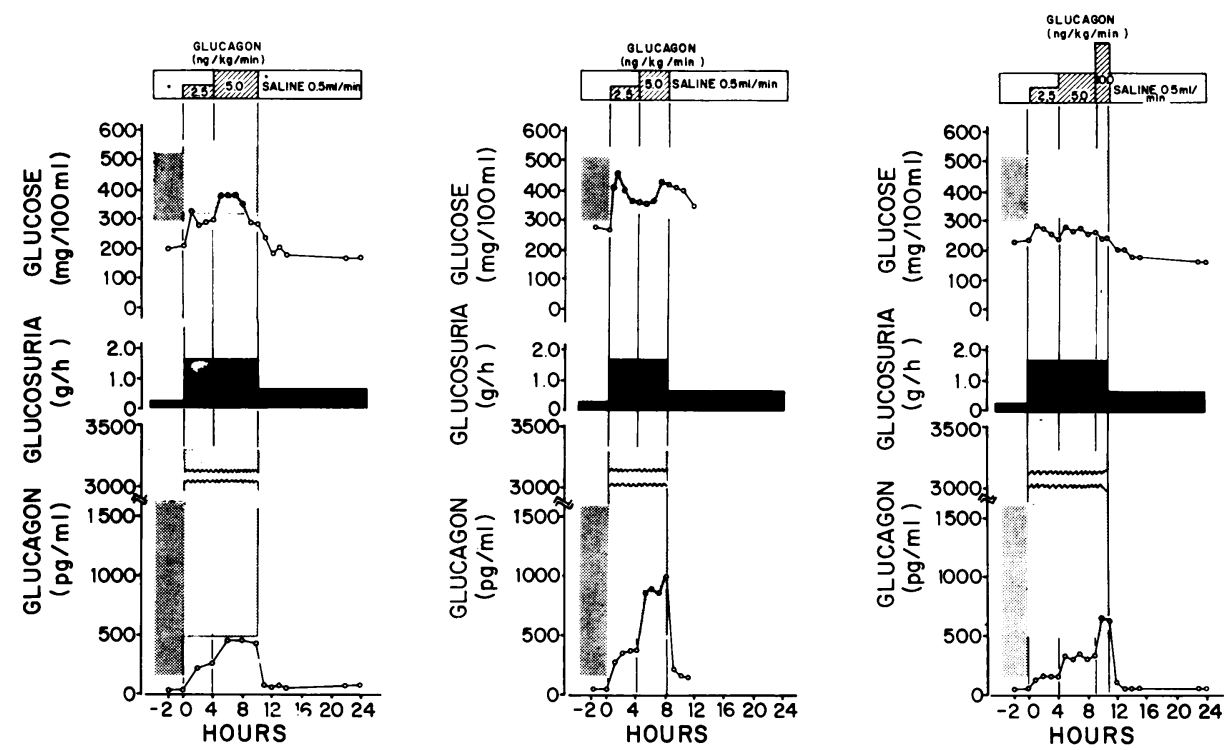

FIGURE 7 Plasma glucose, glycosuria, and IRG levels in three hypoX, depancreatized (Houssay) dogs before, during, and after an 8-11-h infusion with $2.5,5$, or $100 \mathrm{ng} / \mathrm{kg}$ per min of glucagon. The stippled zones in the upper panel represent the range of glucose levels before and during the infusion of arginine in sham-hypoX dogs. The stippled areas in the lower column represent the range of IRG levels before and during the infusion of arginine in sham-hypoX dogs.

the peripheral and portal vein hypoglucagonemia of the hypoX, depancreatized dogs was largely the consequence of a profound reduction in fundic IRG release; simultaneous measurements of IRG in the short gastric vein and inferior vena caval plasma revealed the IRG gradient across the fundus to be only $3 \%$ of that of depancreatized dogs with an intact hypophysis. Despite insulin deficiency, which normally increases gastric IRG secretion (30), the gastric vein-inferior vena cava IRG gradient of hypoX, depancreatized dogs during arginine stimulation was even less than the low levels of intact normal dogs. These results imply that hypoX dogs lack a factor that not only maintains normal gastric IRG secretion but is necessary for the "functional hypertrophy" of IRG secretion that develops in insulin-deficient depancreatized dogs (21).

The mechanisms of the attenuation of hyperglycemia in the face of complete insulin deficiency in hypoX, depancreatized dogs are not identified by these studies. Starvation and glucocortoid deficiency are unlikely explanations, inasmuch as food intake was identical in all groups and replacement therapy with cortisol was provided. Glycogen depletion and hepatic insensitivity to glucagon also seem improbable in view of hyperglycemic responses to arginine-induced glucagon secretion and during the administration of glucagon. The prompt rise in plasma glucose levels observed within $60 \mathrm{~min}$ after the start of a replacement infusion of glucagon, and the eightfold increase in glycosuria indicates that hypoglucagonemia may have contributed to the attenuation of the diabetes of the hypoX, depancreatized dogs. This indicated that the animals were sensitive to exogenous glucagon and that hypoglucagonemia may have contributed to the less severe nature of the diabetes of the Houssay dogs. However, this in no way minimizes the importance of the other hormonal deficits resulting from hypoX.

\section{ACKNOWLEDGMENTS}

The authors wish to thank Dr. Haruhide Ito for his instruction in the technique of hypophysectomy; Mr. Willie McFarland for surgical assistance; Loretta Clendenen, John Diffie, Helen Gibson, Virginia Harris, Sara Innis, Kay McCorkle, Daniel Sandlin, and Lee Schmoker for technical assistance; and Susan Freeman, Jessie Reese, and Carole Tower for secretarial assistance.

This work was supported by Veterans Administration Institutional Research grant 549-8000-01; Fonds National Suisse de la Recherche Scientifique grant no. 3.120.77; National Institutes of Health grant AM02700-16 and contract no. N01AM-6-2219; Ciba-Geigy Corporation, Ardsley, N. Y.; Upjohn Company, Kalamazoo, Mich.; Bristol Myers Corporation, New York; Eli Lilly Company, Indianapolis, Ind.; Karl Thomae $\mathrm{GmbH}, \mathrm{W}$. Germany; American Hoechst Corporation, Somerville, N. J.

\section{REFERENCES}

1. Houssay, B. A., and A. Biassotti. 1930. La diabetes pancreatica de los perros hipofisoprivos. Rev. Soc. Argent. de Biol. 6: 251-296.

2. Houssay, B. A. 1936. Carbohydrate metabolism. N. Engl. J. Med. 214: 971-986. 
3. Lukens, F. D. W., and F. C. Dohan. 1938. Further observation on the relation of the adrenal cortex to experimental diabetes. Endocrinology. 22: 51.

4. Houssay, B. A. 1942. Advancement of knowledge of the role of the hypophysis in carbohydrate metabolism during the last twenty-five years. Endocrinology. 30: 884-897.

5. Marco, J., C. Calle, D. Roman, M. Diaz-Fierros, M. L. Villanueva, and I. Valverde. 1973. Hyperglucagonism induced by gluco-corticoid treatment in man. N. Engl. J. Med. 288: 128-131.

6. Wise, J. K, R. Hendler, and P. Felig. 1973. Influence of glucocorticoids on glucagon secretion and plasma amino acid concentrations in man. J. Clin. Invest. 52: 2774-2784.

7. Glasser, S. R., and J. L. Izzo. 1962. The influence of adrenalectomy on the metabolic actions of glucagon in the fasted rat. Endocrinology. 70: 54-61.

8. Friedmann, N., J. H. Exton, and C. R. Park. 1967. Interaction of adrenal steroids and glucagon on gluconeogenesis in perfused rat liver. Biochem. Biophys. Res. Commun. 29: $113-119$.

9. Bornstein, J., E. Reid, and F. G. Young. 1951. The hyperglycemic action of blood from animals treated with growth hormone. Nature (Lond.). 168: 903-905.

10. Foà, P., E. B. Magid, M. D. Glassman, and H. R. Weinstein. 1953. Anterior pituitary growth hormone (STH) and pancreatic secretion of glucagon (HGF). Proc. Soc. Exp. Biol. Med. 83: 758-761.

11. Tai, T-Y., and S. Pek. 1976. Direct stimulation by growth hormone of glucagon and insulin release from isolated rat pancreas. Endocrinology. 99: 669-677.

12. Sirek, A., M. Vranic, and O. V. Sirek. 1977. Effect of a single somatotropin (STH) injection on plasma insulin and glucagon levels of the dog. Abstract of XXVII International Congress of Physiological Sciences, Paris. In press.

13. Lawrence, A. M. 1972. Pancreatic alpha-cell function in miscellaneous clinical disorders. In Glucagon Molecular Physiology, Clinical and Therapeutic Implications. P. J. Lefebvre and R. H. Unger, editors. Pergamon Press, Oxford. 262-264.

14. Gerich, J., V. Schneider, M. Langlois, C. Noacco, and P. H. Forsham. 1973. Glucagon secretion in acromegaly. Program, 55th Annual Meeting of the Endocrine Society. A-173.

15. Sutherland, E. W., and C. deDuve. 1948. Origin and distribution of the hyperglycemic-glycogenolytic factor of the pancreas. J. Biol. Chem. 175: 663-674.

16. Sasaki, H., B. Rubalcava, D. Baetens, E. Blazquez, C. B. Srikant, L. Orci, and R. H. Unger. 1975. Identification of glucagon in the gastrointestinal tract. J. Clin. Invest. 56: $135-145$.
17. Vranic, M., R. Engerman, K. Doi, S. Morita, and C. C. Yip. 1976. Extrapancreatic glucagon in the dog. Metab. Clin. Exp. 25 (Suppl. I): 1469-1473.

18. Blazquez, E., L. Muñoz-Barragan, G. S. Patton, L. Orci R. E. Dobbs, and R. H. Unger. 1976. Gastric A-cell function in insulin-deprived depancreatized dogs. Endocrinology. 99: 1182-1188.

19. Vranic, M., S. Pek, and R. Kawamori. 1974. Increased "glucagon immunoreactivity" in plasma of totally depancreatized dogs. Diabetes. 22: 905-912.

20. Matsuyama, T., and P. P. Foà. 1974. Plasma glucose, insulin, pancreatic, and enteroglucagon levels in normal and depancreatized dogs. Proc. Soc. Exp. Biol. Med. 147: $97-102$.

21. Mashiter, K., P. E. Harding, M. Chou, G. D. Mashiter, J. Stout, D. Diamond, and J. B. Field. 1975. Persistent pancreatic glucagon but not insulin response to arginine in pancreatectomized dogs. Endocrinology. 96: 678-693.

22. Crowe, S. J., H. Cushing, and J. Homans. 1910. Experimental hypophysectomy. Bull. Johns Hopkins Hosp. 21 : $127-169$.

23. Schmidt, F. H. 1963. Enzymatische Methoden zur Bestimmung von Blutund Harnzucker under Berucksichtigung von Vergleichsuntersuchungen mit Klassischen Methoden. Internist. 4: 554-5.59.

24. Yalow, R. S., and S. A. Berson. 1960. Immunoassay of endogenous plasma insulin in man. J. Clin. Invest. 39: $1157-1175$.

25. Herbert, V., K-S. Lau, C. W. Gottlieb, and S. J. Bleicher 1965. Coated charcoal immunoassay of insulin. J. Clin. Endocrinol. Metab. 25: 1375-1384.

26. Faloona, G. R., and R. H. Unger. 1974. Glucagon. In Methods of Hormone Radioimmunoassay. B. M. Jaffe and H. R. Behrman, editors. Academic Press, Inc., New York. 317-330.

27. Assan, R., and N. Slusher. 1972. Structure/function and structure/immunoreactivity relationships of the glucagon molecule and related synthetic peptides. Diabetes. 21 : 843-855.

28. Faloona, G. R. 1972. The structure-function relationships of pancreatic glucagon. In Glucagon Molecular Physiology, Clinical and Therapeutic Implications. P. J. Lefebvre and R. H. Unger, editors. Pergamon Press, Oxford. 201-204

29. Van Lan, V., N. Yamaguchi, M. J. Garcia, E. R. Ramey, and J. C. Penhos. 1974. Effect of hypophysectomy and adrenalectomy on glucagon and insulin concentration. Endocrinology. 94: 671-675.

30. Muñoz-Barragan, L., E. Blazquez, G. S. Patton, R. E Dobbs, and R. H. Unger. 1976. Gastric A-cell function in normal dogs. Am. J. Physiol. 231: 1057-1068. 